\title{
皮膚電位活動に及ぼす電極圧迫の影響と性差
}

\author{
東京都神経科学総合研究所 石原金由 ${ }^{1)}$ \\ 関西学院大学 宮田 洋
}

\section{Effects of pressure and sex differences on skin potential activity}

\author{
ISHIHARA, Kaneyoshi \\ Department of Psychology, \\ Tokyo Metropolitan Institute for Neurosciences, \\ Fuchu 183 \\ MiYATA, Yo \\ Department of Psychology, Kwansei Gakuin University, \\ Nishinomiya 662
}

\begin{abstract}
The present study was to investigate the effects of pressure and sex differences on skin potential activity (SPA), using 10 male and 10 female students. Although skin potential level (SPL) was decreased instantly after pressing the electrode site, subsequently SPL was changeless, i. e., flattening pattern, compared with SPL on control side. The frequency of skin potential responses (SPRs) was decreased, and no effect on the negative component of amplitude while the positive component was significantly abolished on the pressure side. As to the interpretation of these results, following possible factors were suggested : (1) sweat pore occlusion by the pressure, (2) the effects of pressure reflex, and (3) local ischemia resulting from the pressure. Sex differences on SPA were also evidently observed. There were significantly higher SPLs and greater frequency in SPRs in males than in females. Thus, it was suggested that the use of any subject group that consisted of both males and females should be avoided when electrodermal activity is employed as psychophysiological measure.
\end{abstract}

Key words : skin potential activity, pressure, sex differences, sweat-pore occlusion, local ischemia.

皮膚表面を压迫するととによって，発汗は抑制 されるととが知られている。Takagi \& Sakurai (1950) は，身体の片側を圧迫すると，圧迫さ れた側では発汗が抑制されるととを報告しており，

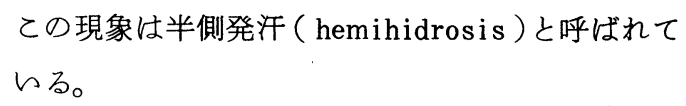

この現象は半側発汗 (hemihidrosis) と呼ばれて レる。

汗腺活動と密接に関連している皮膚電気活動

(electrodermal activity：EDA) もまた, 圧

1）実験の実施にあたり，齋藤 敬氏（日本 I B M ) の協力を得をした。また，本論文の作成にあたっ ては, 小川徳雄先生 (愛知医科大学教授) ならびに宮下彰夫先生 (東京都神経科学総合研究所) か ら多くの助言をいただをました。諸氏に感謝します。

1984 . 8. 23 受稿

1984. 11 . 7 受理 
迫によって影響を受ける。すなわち，皮膚抵抗水 準 (skin resistance level：SRL) は増加し, 皮膚抵抗反応 ( skin resistance response : S R $R$ ）す出現しにくくなる。一方, 皮膚電位反応 ( skin potential response : SPR) は振幅の減 少および二相性波形の陰性単相波化が報告されて レる(宮下, 1984 ; Nakayama \& Takagi,

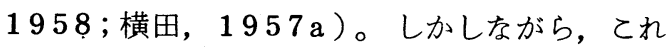
らの研究は, 体幹部もしくは指のつけねを圧迫し た時のるのであり, 直接電極装着部位を圧迫した ものではない。

精神生理学的指標としてED A を用いて実験を する場合, 電極を過度に圧迫して装着したり, あ るいは実験中, 被験者が電極装着部位を何らかの 形で押していると，E D Aの結果は不当に歪めら れてしまら可能性がある。本研究の目的は, 直接 電極部位を圧迫した場合の皮膚電位活動 ( sk in potential activity：SPA）が受ける影響を調 べ, S P Aの発現メカニズムについても若干の検 討を加えたい。をた，あわせてS P Aの性差につ レても検討し, 従来の知見と比較する。

\section{方法}

被験者 大学生 20 名 (18 23 歳, 平均 20.6 歳) が被験者として用いられ, 内訳は男女各 10 名ずつであった。

装 置 S P A は, 高感度直流増幅器 (東亜電 波製，CDR-12A）を用いて，紙送り速度 60 $\mathrm{mm} / \mathrm{min}$ で記録された。電極は, 渡辺・山崎・新 美（1969）による $\mathrm{Ag}-\mathrm{AgCl}$ 電極が作製され，そ の中から電極間電位差が土 $0.3 \mathrm{mV}$ 以下の対を選 択し用いた。電極は, $0.06 \mathrm{~mol} \mathrm{NaCl}$ 寒天電解質 を介して, 以下の部位に装着された。探査部位と して左手第 2,3 指末節掌側, 無関部位は, skin drilling 法 (Shackel, 1959) 飞よって不活性 化処理が施された同側前腕内側であった。

手 続 被験者は, 椅座で安静閉眼および深呼 吸を 2 分間ずつ行った後，第 2 指をたは第 3 指の
電極装着部位を圧迫し, 再び安静閉眼, 深呼吸を 2 分間ずつ行った。その後, 5 分間の安静期をお いた後, 脱圧し, 再度 5 分間の安静期をおいた。 深呼吸は, S P R を誘発する手段として用いられ (Fowles \& Rosenberry, 1973 ), 呼吸の速さ および梁さは，記録を見ながらインタホンを通し て適宜被験者に指示された。

電極部位の加圧は，Fig. 1 亿示されるように 大型の洗濯ばさみで電極部位をはさむととによっ て行った。加压值は, 被験者の指の厚さの個人差

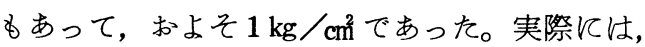
実験終了後に電極を取り除くと，皮膚表面に明確 な電極の跡がすべての被験者に認められた程度で あった。加圧する指は，カウンタバランスされた。 室温は $22.3 \pm 0.8^{\circ} \mathrm{C}$, 湿度は $56.7 \pm 6.9 \%$ でっ た。

資料の整理 皮膚電位水準 ( skin potential level：SPL)およびSPRの読み取りは, 石原・ 宮田 (1980a) 飞従って, S P Lは 30 秒毎に計 測され， 1 分毎に平均值を算出した。また, SPR は $0.2 \mathrm{mV}$ 以上の反応飞つ々て, 㓌性単相波, 二 相性波, 陽性単相波飞分類され, 頻度および振幅 が計測された。

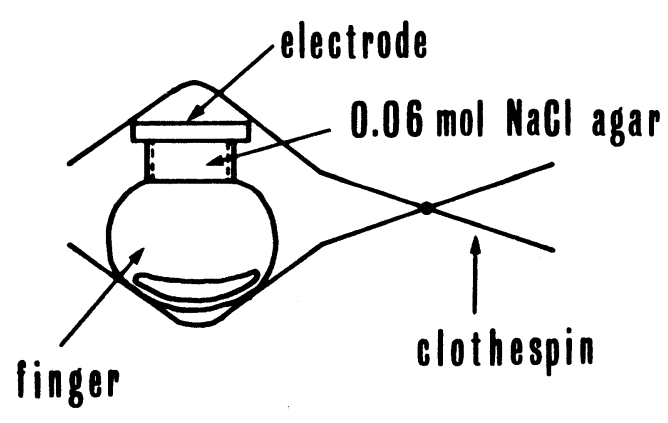

Fig. 1. Schematic presentation of the method of pressure. 
結

果

S P L は通常陰性電位なので, 各Fig.の中では 便宜上，絶対值で示してある。したがって，S P Lの低下もしくは減少は，陽性方向への変化を意 味する。

圧迫の効果

S P L Fig. 2 は, 時間経過に伴ら圧迫・非 圧迫指のS P Lの変化を示したものである。压迫 前のS P L は, 圧迫指, 非圧迫指とに差は認めら れないが，匟迫した時点で，压迫指のＳＰＬは急 激に低下し(Fig. 2 の 4 分目から5 分目)，その 後深呼吸による一時的上昇を除らて，あまり変化 せず，一定のレべルを保っている。一方，非圧迫 指は深呼吸によるS P Lの一時的上昇を除くと, 漸減傾向が認められ，てとに梁呼吸の後では，圧 迫指と比較して 6〜 $7 \mathrm{mV}$ 低下している。脱圧後, 圧迫指のS P L は急激に増加するとともなければ, 非圧迫指のS P L 值にまで回復することもなく, 圧迫中と同様に非圧迫指よりも高い電位を示して 々万。压迫前, 圧迫中, 脱圧後の平均 S P L 值を 用いて 2 要因 (压迫 $\times$ 時間) の分散分析を行った 結果, 压迫および時間の主効果, 圧迫 $\times$ 時間の交 互作用が有意であった（圧迫：F( 1,19$)=6.85$,

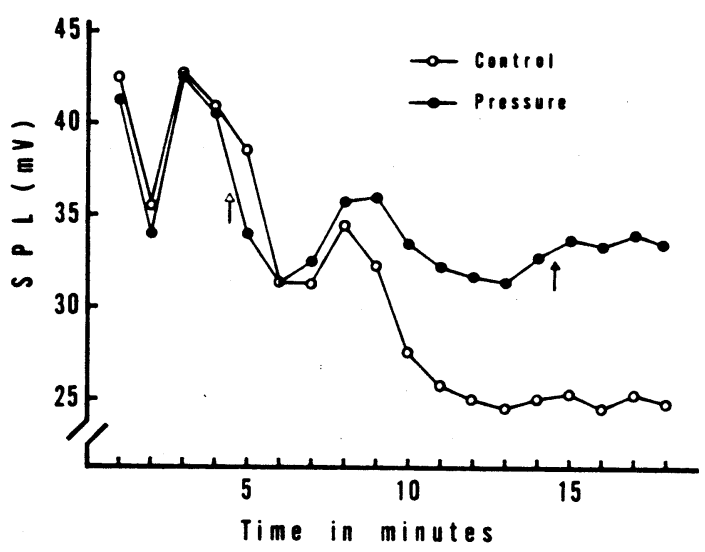

Fig. 2. Mean SPL changes on the control and pressure sides. (ㅅ) : Beginning of pressure, $(\boldsymbol{4})$ : Termination of pressure.
$P<.025$; 時間 : $F(2,38)=75.66, P<$ .001 ; 厌迫 $\times$ 時間: $F(2,38)=60.91$, $P<.001$ )。

S P R Fig. 3 は, 圧迫指之非圧迫指のS P $\mathrm{R}$ 頻度を圧迫前，圧迫中，脱圧後で表わしたもの である。压迫中の S P R頻度は，厈迫指で減少し ているのがわかる。同様の傾向は, 脱压後にも認 められる。2 要因の分散分析の結果, 圧迫和よび 時間の主効果, 圧迫 $\times$ 時間の交互作用が有意であ った（压迫： $F(1,19)=7.23 ， P<.05$; 時間 : $F(2,38)=24.70, P<.001 ;$ 圧迫 ×時間 : $F(2,38)=6.63, P<.005)$ 。次 V S P R 頻度を波形別とみると, Table 1 で示 される。Table 1 は, 非圧迫指で各種波形の $\mathrm{S}$ P Rが出現した時, 対照の圧迫指ではどのような 波形を示したかを表わしている。压迫前では, 非 圧迫指と压迫指の波形は压济一致している。しか しながら, 圧迫中は, 非圧迫指で反応が出現して いたにもかかわらず，压迫指での無反応 (NR)の 頻度が増加している。ま, 非圧迫指で二相性波

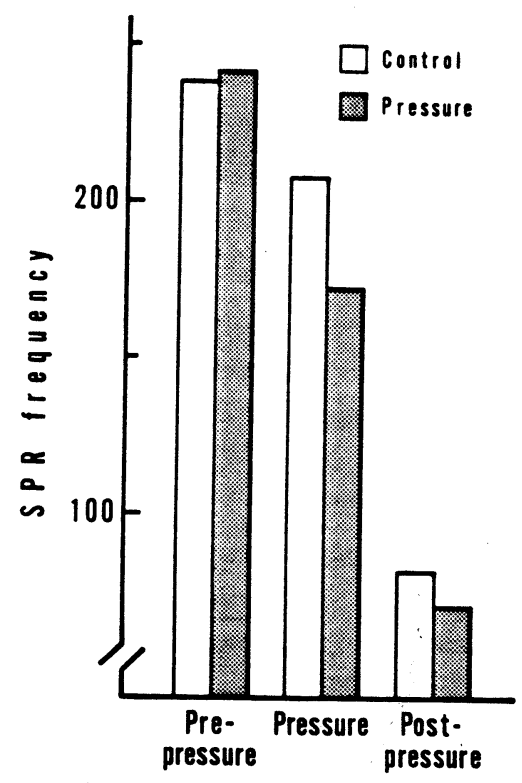

Fig. 3. Frequency of SPRs during three epochs. 
Table 1. The number of SPRs in each wave-form on pressure side at the time when various wave-forms of SPRs occurred on control side (Degree of coincidence of SPR wave-forms ).

\section{Pressure side}

\begin{tabular}{|c|c|c|c|c|c|c|c|c|c|c|c|}
\hline \multicolumn{4}{|c|}{ Pre-pressure } & \multicolumn{4}{|c|}{ Pressure } & \multicolumn{4}{|c|}{ Post-pressure } \\
\hline $\mathrm{N}$ & D & $P$ & NR & $\mathrm{N}$ & D & $P$ & NR & $\mathrm{N}$ & $D$ & $P$ & NR \\
\hline 34 & 3 & & 2 & 110 & 3 & & 41 & 62 & 2 & & 18 \\
\hline \multirow[t]{2}{*}{2} & 70 & & & 16 & 9 & 4 & 2 & & 2 & & \\
\hline & 1 & 30 & & 7 & & 7 & 6 & 3 & & & 1 \\
\hline
\end{tabular}

\section{$\mathrm{N}$ : Negative wave $\mathrm{D}$ :Diphasic wave $\mathrm{P}:$ Positive wave $\mathrm{NR}$ : No response}

（D）あるレは陽性単相波 (P) が出現した時に, 圧 迫指で陰性単相波 $(\mathrm{N})$ の出現しているととがわか る。S P Rの振幅とついては, 陰性成分と陽性成 分に分けて分析がをされた (Fig. 4)。陰性成分 （Fig. 4 a ）については，压迫中にSPRが出現し なかった 3 名を除を，压迫前および圧迫中の平均 振幅を用いて 2 要因の分散分析 (圧迫 $\times$ 時間) が なされた。その結果，いずれの要因にも差は認め られなかった。陽性成分 (Fig. 4 b) 飞関しては, 圧迫中に二相性波あるいは陽性単相波の出現した 者が 6 名のみであったため, この 6 名について陰 性成分々同様の分析が行われた。分散分析の結果, 压迫×時間の交互作用のみが有意で，压迫の主効 果については傾向にとどまった（压迫×時間：F $(1,5)=27.67, P<.005 ;$ 圧迫 $: F(1,5)$ $=6.27, P<.1)$ 。振幅関する結果は, 压迫 によって陽性成分のみが減少したととを示してい る。

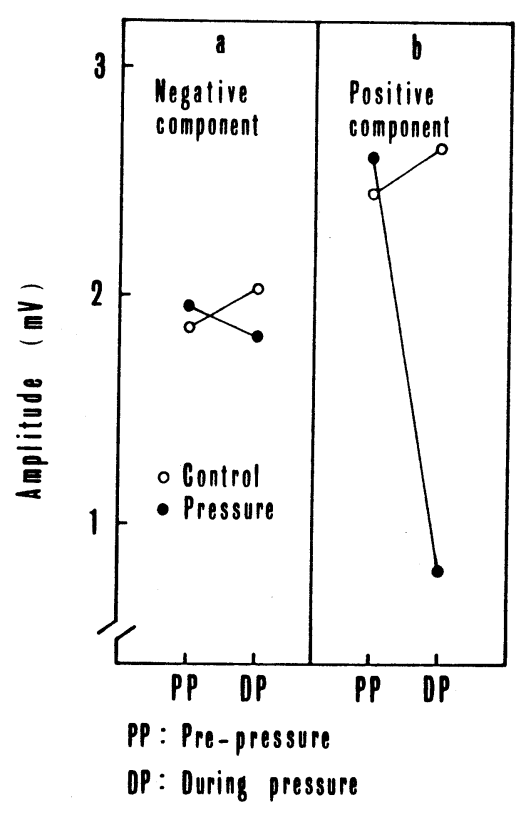

Fig. 4. Amplitudes of negative and positive components in preand during pressure epochs. 
性 差

分析には非圧迫指から得られた S P Aデータの みが用いられた。

S P L Fig. 5 は，男女別 S S P D の変化を 示したものである。測定中の 3 区間（圧迫前，圧 迫中, 脱圧) の平均 S P L 值を用いて 2 要因（性 差×時間）の分散分析を行った結果，性差および 時間の主効果が有意であった（性差：F( 1,18 ) $=13.25, P<.005$; 時間 $: F(2,36)=199.48$, $P<.001)$ 。Fig. 5 からも明らかなよらに, 男性の方が，S P L值はおよそ $12 \mathrm{mV}$ 高かった。

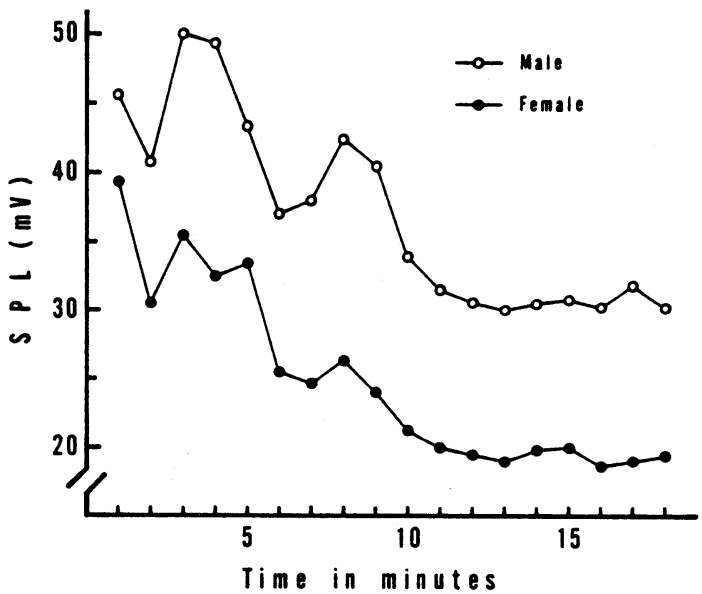

Fig. 5. Mean SPL changes in male and female subjects.

S P R Fig. 6 で示されるよらに， S P R 頻 度は男性の方が多かった。 S P L同様に S P R 頻 度についても分散分析をした結果，性差および時 間の主効果が認められた（性差：F(1,18)= $5.12, P<.05$; 時間 : $F(2,36)=18.81$, $P<.001)$ 。振幅の分散分析は, 陰性成分につ らてのみ行われたが, 性差は認められなかった。 陽性成分については，前述したように使用しらる 例数が 6 例（男性 4 名，女性 2 名）と少なかった ため, 分散分析は行えなかった。しかしながら， 圧迫前のみの平均振幅は, 男性 $(\mathrm{N}=9)$ で 2.65 $\mathrm{mV}(\mathrm{SD} 1.28)$, 女性 $(\mathrm{N}=6)$ で $1.3 \mathrm{mV}$ ( $\mathrm{S}$
D 1.00 ）で, $\mathrm{t}$-検定の結果, 性差の傾向を認め た $(t=2.03, d f=13, P<.1)$ 。

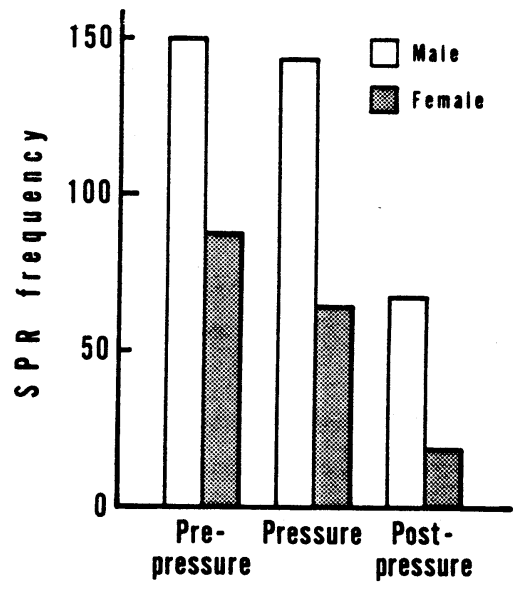

Fig. 6. Frequency of SPRs in male and female subjects during three epochs.

\section{考察}

圧迫の効果 S P Aへの圧迫効果は顕著に認め られた。SPLは圧迫直後急激に低下したものの, その後は，后とんど変化せず，非圧迫指に比較し て高くなった（Fig. 2)。脱圧後も，压迫指の S P L は変化せず，压迫中と同様に非圧迫指よりも 電位は高かった。S P R つつても，圧迫による 頻度減少（Fig. 3) および二相性波や陽性単相波 の陰性単相波化の現象が認められた。また，圧迫 によって陽性成分の振幅も大きく減少した。乙れ らの結果は, S P L を除いて, 過去の研究

(Nakayama \& Takagi, 1958 ; 横田, 1957 a ）と一致している。

S P A の発現と密接に関連のある汗腺および発 汗現象は，压迫によってかなり複雑な影響を受け ると思われる。まず S R Rついて考えてみると， 以下のような要因があげられる。

第 1 に，王迫による汗口の閉鎖である(小川 ${ }^{2}$;

2) 小川德雄 ( 1984 年, 6 月, 私信 $)$ 
Shuster, 1963$)$ 。さらに, S P A測定に用い られた電極電解質 ( $0.06 \mathrm{~mol} \mathrm{NaCl}$ 寒天) 亿よる 表皮湿潤も加わって，汗口閉鎖は促進されると考 えられる。この汗口閉鎖によって発汗は抑制され るととが知られているが，汗腺自体の活動を抑制 するものではない(Papa \& Kligman, 1966 )。 湿潤による汗口閉鎖がS P A K及侉す影響は, S P L の低下, S P R 頻度の減少, 振幅一とく 飞陽性成分の減少で特徵づけられており（Edelberg, 1968 ; Fowles \& Rosenberry, 1973 ; Fowles \& Schneider, 1978 ; Fowles \& Venables, 1970 ; 石原・宮田, $1980 \mathrm{~b}$; 石原・齋 藤・宮田， 1980 ; 奥田・丹治・清水・山崎・新 美，1970），SPRの陽性成分の発現は，表皮の 表層部に由来するととが示唆されている( 奥田ら, 1970 )。湿潤によるS P R一の影響は, 本研究 結果と一致しているものの, S P Lの方は, 圧迫 中, 無処置側に比べて相対的に高くなっており, 湿潤効果とは考え難い。

本研究では, 圧迫・非圧迫指とも寒天電解質を 用いており，湿潤による汗口閉鎖の程度は同じで あろう(ただし, 压迫によって湿潤が促進される 可能性もある)。同じ汗口閉鎖の現象でも, 压迫 によるものと, 湿潤によるものとでは, 表皮の状 態が異なるのではないかと思われる。したがって， 本実験で得られた S P L および S P R 結果は, 少くとも湿潤による汗口閉鎖のみではなく，压迫 によるそれが関与していると考えられる。

第 2 にあげられる要因は, 圧迫による反射的発 汗抑制で，皮膚圧一発汗反射と呼ばれるるのであ る。手掌は压に対してかなり敏感で, 圧一発汗反 射が起とり易いと考えられる。 ついては, いまだ明らかではないが，小川・朝山・ 伊藤 (1981) は, 皮膚圧によって生じた知覚神 経衝撃が春髄分節レペルで発汗遠心路に干渉し, 発汗抑制をもたらすと推測している。したがって， 圧迫による発汗抑制は，汗腺自体の活動が抑制さ

3）小川徳雄 ( 1984 年, 6 月, 私信)
れるととによって生起する。 Nakayama \& Takagi ( 1958 ) は, 右側卧位（すなわち右体側の 圧迫）でのS P R は, 圧迫側での振幅减少や, 非 圧迫側で二相性波形が出現している時に圧迫側で は陰性単相波が出現していたととを報告している。 彼らはS P LやS P R頻度については述べてはい ないが, 波形に関しては本研究と一致している。

第 3 亿, 圧迫によって2 次的飞生起する血行障 害である(Nakayama \& Takagi, 1958 )。阻 血 ( i schemia), 駆血 (exsanguination), ある レは動脈閉塞 (arterial occlusion) がS P R 及深す影響は，圧迫や湿潤による結果と類似して いる。すなわち, 無処置側が二相性波・陽性単相 波でも, 処置側では陰性単相波がみられ（Nakayama \& Takagi, 1958 ; Wilcott, 1958 , $1962 \mathrm{~b}$; 横田, $1957 \mathrm{~b}$ ), 陰性成分の振幅飞 は差が認められなかった（Wilcott，1958)。乙 れらの研究では, 駆血等の手続きとゴム製包帯が 使用されでり，てれを巻さつけるととによって 血行障害を起こさせている。ただし，本研究のよ らに電極部位を直接圧迫していたのではなく、ま た，その压迫力や血行障害の程度も異なっていた と思われる。おそらく，ゴム製包帯の方が，圧迫 力・血行障害の程度ではまさっていたであろう。

上述の 3 要因が S P R 亿及湀す影響は，かなり 類似しており，どの要因が主として本結果に影響 を与えたのかは結論でをない。しかし，陽性成分 の消失あるいは振幅減少については，汗口閉鎖の 結果, 汗が表皮導管部に到達できないととが主要 因と思われる。汗口閉鎖が生起していないはずの 駆血等の研究 (Nakayama \& Takagi, 1958 ; Wilcott, $1958,1962 \mathrm{~b}$; 横田, $1957 \mathrm{~b})$ で も同様の結果が得られたととは，和そらく，血行 障害が発汗量の減少をもたらすため(小川，1982）， 汗が表皮導管部まで充満しなかったであろらとい うことで説明でをるかもしれない。Wilcott ( $1962 \mathrm{a}, \mathrm{b}$ ) は, 発汗反応と S P A を同時記録 したとてろ，SPRの陰性成分は発汗反応より先 
行して出現しており，陽性成分は発汗反応と同時 に出現したことを報告した。さらに，駆血中には 発汗反応がないにるかかわらず，陰性単相波は出 現しているてとからも(Wilcott, $1962 \mathrm{~b}), \mathrm{S}$ P Rの陽性成分は，汗が表皮表層部に到達した時 飞生起する電気的変化であり, 陰性成分は近位導 管部ないしは分泌コイル付近の電気的変化を反映 していると考えられる。

次にS P L についてであるが, 圧迫がS P L K 及济す影響を報告した研究はない。わずかにWil$\operatorname{cott}(1958)$ が駆血および動脈閉塞時のS P L を報告しているが，一貫したS P L変化は認めら れなかった。しかしながら, 本研究では, 压迫直 後の低下とその後のレベル変化に乏しかったとと が示されており，Wilcottの結果と一致しない。 また，既述したように表皮湿潤による汗口閉鎖で も説明しえない。それゆえ, 本研究でのS P Lの 結果は，直接電極の上から压迫したととによるも のと思われる。ただし，どのようなメカニズムが このよらな結果を生起させたかは不明である。し かし，厈迫が汗口閉鎖だけでなく，汗腺の深部に まで何らかの影響を及淩したか，あるいは，同じ 汗口閉鎖の現象でも，圧迫によるのと湿潤による のとでは，表皮の状態が異なっていたというよう なととが考えられるかもしれない。いずれにせよ， 今後さらに検討する必要があろう。

脱圧後，S P LおよびS P R が急速な回復を示 さなかったととは興味深い。駆血等の研究では, いずれも 15 分から 25 分間の処置をしているに もかかわらず( Nakayama \& Takagi, 1958 ; Wilcott, $1958,1962 \mathrm{~b}$; 横田, $1957 \mathrm{~b}$ ), 処置終了後, 寸みやかに回復しているととから

(Wilcott, 1958 ), 本結果が血行障害によるる のではないととを推測させる。王迫の残存効果か, あるいは压迫によって圧迫指の湿潤効果が促進さ れたのかもしれないが, 少くとも S P L の結果を みる限り, 湿潤効果とも考允難い。

脱王後の測定時間が短かったとともあって, 回
復にどの程度の時間がかかるかはわからないが, わずか 10 分程の圧迫でてのような現象が生起す るととは, 今後, 実験事態で充分注意すべをであ ろ5。

性差 S P A 亿関する性差の報告は少なく, Christie \& Venables ( 1971 b) がS P LKつ らて女性の方が低いと述べている。ての結果は, 本結果と一致している。皮䖉伝導度変化を用いた 性差の研究では, Kopacz \& Smith(1971)が 電気ショックに対する脅威感を 3 段階に操作して 検討している。皮膚伝導度水準に関しては, 男性 の方が高く（SRLでは低い），一方，女性は男性 と比較して誘発性反応の振幅増加や自発反応の頻 度増加が報告されている。また, 自発反応頻度で は，劦威レベル×性差の交互作用も認められた。 すなわち, 男性では脅威レベル増加に伴って一次 的に頻度も増加したが，女性では脅威レベルが 0 \%から50\%に変化したとてろで大さく増加した。 誘発反応の振幅叔゙自発反応頻度についての彼 らの報告は, 実験状況が全く異なるため単純に比 較はできないが, 本研究結果と一致しない。

Kopacz らは，乙のような性差が発汗要因によ るものではなく, 非発汗性, とくに性ホルモン機 能の差によると示唆している。同様の示唆は, Broverman, Klaiber, Kobayashi \&:Vogel (1968), Christie \& Venables (1971b), Shmavonia, Miller \& Cohen(1968) K よってもなされている。また，Baitsch（1954） は, 思春期前では皮膚抵抗変化に性差が見られず, それ以後では, 男性の方が S R L は低く, 反応性 が高いと報告しており，暗に性ホルモンの重要性 を示唆している。

E D Aの発現と関連のある発汗および汗腺の機 能にも性差は認められている。性差が明確に現れ るのは, Baitsch（1954)の報告と一致して思春 期以後であり，性機能が仼とんど終息した高年者 では，再び性差は認められなくなる(田中，1956）。 女性では暑熱負荷による発汗発現までの潜時が男 
性より長く, 発汗量も女性の方が少ない（Fox, Löfstedt, Woodward, Eriksson \& Werkstrom, 1969 ; Morimoto, 1978 )。さらK, 活動汗腺の数は女性の方が多いにもかかわらず ( Juniper \& Dykman, 1967 ; Morimoto, 1978 ), 単一汗腺あたりの分泌量は男性の方が 多く，薬物の局所投与に対する発汗反応子男性の 方が強い(小川，1982)。乙れらの知見から， 本研究で得られた結果のように, 男性の方が $\mathrm{S} P$ Lは高く, S P R 頻度あるいは振幅も大きいと推 測しらるかもしれない。しかし, 発汗反応はS P $\mathrm{R}$ と高い相関があるものの, S P L とは相関がな h(Wilcott, 1962a)。S P L発現機序飞つい ては, 発汗性要因だけでなく, 非発汗性の要因も かなり関与しているてとが指摘されており

(Christie \& Venables, $1971 \mathrm{a}$; 石原・宮田, 1980 a ; Venables \& Martin, 1967 ; Yamazaki \& Tajimi, 1972), 発汗現象のみと結 びつけるのは困難であろう。

本実験で用いられた女性被験者は, 月経周期に ついてコントロールされていなかったものの, S P A K明らかな性差が認められた。このととは， E D A を用いた精神生理学的研究において, 被験 者の構成を男女混合にしないととが望をしいとと を意味している。男女混合で用いた場合，いたず らに標準偏差を大をくし，本来の実験目的を達成 でをない可能性があると思われる。Bell, Christie \& Venable (1975.) やShmavonian,

Yarmat \& Cohen ( 1965 ) 子同様の見解老述 ベてレる。

\section{要 約}

本研究は, S P A 亿及仿す電極圧迫の影響と性 差を検討する目的で行われた。被験者として，大 学生 20 名(男子 10 名, 女子 10 名) が用いら れた。

電極压迫によって S P A は以下のような影響を 受けた。
（1）S P L は圧迫直後に急激に低下したが，その 後は変化に乏しく, 非圧迫指と比較して S P L 值 は高くなった。

（2）S P R とつレては, 頻度の減少および二相性 波・陽性単相波の陰性単相波化が認められた。 た, 振幅につレても, 陽性成分の減少が認められ た。

このよらな結果が得られた主要因として，(1) 圧迫による汗口閉鎖，（2）皮䖉圧一発汗反射によ 万反射的発汗抑制，（3）压迫によって2 次的に生 起する血行障害, が考えられた。

S P Aの性差も顕著であり, 以下のような結果 が得られた。

（1）SPLは，女性に比較して男性の方が高かった。 （2）SPR 頻度も男性の方が多く，振幅について は, 陽性成分飞関してのみ, 男性の方が大きい傾 向が認められた。

これらの結果から，EDAを指標として行ら研 究において, 男女混合の被験者群を構成するとと は避けられるべをであるととが示唆された。

\section{引用文献}

Baitsch, H, 1954 Uber geschlechts und seitendifferenzen im "Niveau"-elektrodermatogramm. Confine Neurol., 14, 88-100.

Bell, B., Christie, M. J., and Venables, P. H. 1975 Psychophysiology of the menstrual cycle. In P. H. Venables and M. J. Christie (Eds.), Research in psychophysiology. London : John Wiley \& Sons, Pp. 181-207.

Broverman, D. M., Klaiber, E. L., Kobayashi, Y., and Vogel, W. 1968 Roles of activation and inhibition in sex differences in cognitive abilities. Psychol. Rev., 75, 23-50.

Christie, M. J., and Venables, P. H. 1971a Characteristics of palmar skin potential and conductance in relaxed human subjects.

Psychophysiology, 8, 523-532. 
Christie, M. J., and Venables, P. H. 1971b

Sodium and potassium electrolytes and "basal" skin potential levels in male and female subjects. Jap. J. Physiol., 21, 659-668.

Edelberg, R, 1968 Biopotentials from the skin surfase : The hydration effect. Ann. NY Acad. Sci., 148, 252-262.

Fowles, D. C., and Rosenberry, R. 1973 Effects of epidermal hydration on skin potential responses and levels. Psychophysiology, 10, 601-611.

Fowles, D.C., and Schneider, R.E. 1978

Electrolyte medium effects on measurements of palmar skin potential. Psychophysiology., 15, 474-482

Fowles, D. C., and Venables, P. H. 1970 The reduction of palmar skin potential by epidermal hydration. Psychophysiology, 7, 254-261.

Fox, R. H., Lofstedt, B. E., Woodward, P. M., Eriksson, E., and Werkstrom, B. 1969 Comparison of thermoregulatory functon in men and women. J. Appl. Physiol., 26, 444-453.

石原金由・宮田 洋 $1980 \mathrm{a}$ 異なる電極電 解質之皮膚電位活動. 心理学研究, 51 , $291-294$.

石原金由・宮田 洋 $1980 \mathrm{~b}$ 皮膚電位活動 とその基礎的背景. 人文論究. 30,75 -94 .

石原金由・斎藤 敬・宮田 洋 1980 皮膚 電位活動に関する基礎的研究（III）一表皮湿 潤効果を除去する電解質の検討一 関西心理学 会第 92 回大会発表論文集, 9 .

Juniper, K., and Dykman, R. A. 1967 Skin resistance, sweat gland counts, salivary flow, and gastric secretion : Age, race, and sex differences, and intercorrelations.

Psychophysiology, 4, 216-222.

Kopacz, F. M., and Smith, B. D. 1971 Sex differences in skin conductance measures as a function of shock threat. Psychophysiology, 8, 293-303.

宮下彰夫 1984 皮膚電位活動測定に関与す る諸要因の検討，早稲田心理学年報，16， $21-28$.

Morimoto, T. 1978 Variations of sweating activity due to sex, age and race. A. Jarrett (Ed.), The physiology and pathophysiology of the skin. Vol. 5, London: Academic Press, Pp. 1655-1668.

Nakayama, T., and Takagi,. 1958 Two components involved in galvanic skin response. Jap. J. Physiol., 8, 21-30.

小川徳雄 19982 エックリン汗腺. 現代皮膚 科学大系 $3 \mathrm{C}$. 皮膚の構造と機能 III. 東京, 中 山書店, $\mathrm{P} \mathrm{p}, 89-109$.

小川徳雄・朝山正己・伊藤嘉紀 1981 皮膚 圧及びハリによる区域的発汗抑制, 自律神経, $18,246-253$. 奥田賢一・ 丹治哲雄 - 清水功一 - 山崎勝男 - 新美 良純 1970 皮虞湿潤による手掌皮膚電位 活動の変化. 心理学研究, 40,158 162 .

Papa, C. M., and Kligman, A. M. 1966

Mechanisms of eccrine anidrosis : 1. High level blockade. J. Invest. Dermatol., 47, 1-9.

Shackel, B, 1959 Skin drilling : A method of diminishing galvanic skin potentials. Am. J. Psychol., 72. 114-121.

Shmavonian, B. M., Miller, L. H., and Cohen, S, I 1968 Differences among age and sex groups in electrodermal conditioning.

Psychophysiology., 5, 119-131. 


\section{生理心理 $\quad 2$ 巻 1984}

Shmavonian, B. M., Yarmat, A. J., and Cohen,

S. I. 1965 Relationships between the autonomic nervous system and central nervous system in age differences in behavior. In A,T. Welford and J. E. Birren (Eds.),

Behavior, aging and the nervous system. Springfield : Thomas.

Shuster, S. 1963 Graded sweat-duct occlusion : A technique for studying sweat-gland function. Clin. Sci., 20, 89-95.

Takagi, K., and Sakurai, T. 1950 A sweat reflex due to pressure on the body surface. Jap. J. Physiol., 1, 22-28.

田中正巳 1956 発汗性に影響を及ぼす生物 学的要因の研究一第 2 報, 発汗性の性的差異. 日本生理誌, $18, \quad 395-397$. Venables, P. H., and Martin, I, 1967 The relation of palmar sweat gland activity to level of skin potential and conductance. Psychophysiology., 3, 302-311.

渡辺尊己・山崎勝男・新美良純 1969 皮膚
電位水準および皮虐電位反射測定の方法論的諸 問題、 精神経誌, 71, 17-31.

Wilcott, R. C. 1958 Effects of local blood removal on skin resistance and potential. $J$. Comp. Physiol. Psychol., 51, 295-300.

Wilcott, R. C. 1962a Palmar skin sweating vs. palmar skin resistance and skin potential. $J$. Comp. Physiol. Psychol., 55, 327-331.

Wilcott, R, C. 1962b Effects of exsanguination on sweating and skin potential response. $J$. Comp. Physiol. Psychol., 55, 1136-1137.

Yamazaki, K., and Tajimi, T. 1972 What is skin potential level? Psychophysiology., 9, 650-652.

横田敏勝 $1957 \mathrm{a}$ 皮膚電気反射の本態に関 する研究, 日本生理誌, 19,98 . 横田敏勝 $1957 \mathrm{~b}$ 皮膚電気反射に関する研 究, 日本生理誌, 19,724 725 . 